\title{
Microcyclus ulei races in Brazil
}

\author{
João Alberto Zago Bevenuto'; José Raimundo de Souza Passos²; Edson Luiz Furtado ${ }^{1}$.
}

${ }^{1}$ UNESP - Univ Estadual Paulista - Faculdade de Ciências Agronômicas - Dept. of Plant Protection - 1780 Lageado Experimental Farm - 18610 307 - Botucatu, SP - Brazil. ${ }^{2}$ UNESP - Univ Estadual Paulista - Instituto de Biociências de Botucatu - Dept. of Biostatistics - S/N Distrito de Rubião Júnior - 18618-970 - Botucatu, SP - Brazil.

Autor para correspondênbcia: João Alberto Zago Bevenuto (jbevenuto@yahoo.com.br)

Data de chegada: 21/11/2016. Aceito para publicação em: 07/06/2017.

$10.1590 / 0100-5405 / 172339$

\section{ABSTRACT}

Bevenuto, J.A.Z.; Passos, J.R.S.; Furtado, E.L. Microcyclus ulei races in Brazil. Summa Phytopathologica, v.43, n.4, p.326-336, 2017.

The fungus Microcyclus ulei is the causative agent of leaf blight in rubber trees, which is one of the most important diseases affecting this crop, since it causes intense defoliation. Several races of this pathogen have been described in Brazil based on a series of diverse differential clones. According to the reactions of 11 differential clones already reported in the literature (MDF 180, Fx 3844, Fx 985, Fx 4098, Fx 2261, Fx 2804, Fx 3899,
IAN 6158, IAN 3087, IAN 717 and PA 31), containing the species Hevea brasiliensis, Hevea benthamiana and Hevea pauciflora, a cluster analysis of the binary data referring to virulence of this disease was performed by using the Jaccard method. The cluster analysis was fitted according to the centroid method. Results indicated the existence of 53 different races of this pathogen in Brazil.

Keywords: Rubber tree, leaf blight disease, differential clones, multivariate analysis.

\section{RESUMO}

Bevenuto, J.A.Z.; Passos, J.R.S.; Furtado, E.L. Raças fisiológicas de Microcyclus ulei no Brasil. Summa Phytopathologica, v.43, n.4, p.326-336, 2017.

O fungo Microcyclus ulei é o agente causador da doença do mal das folhas em seringueira, sendo esta doença umas das mais importantes nesta cultura, visto a intensa desfolha que causa nas plantas. Varias raças deste patógeno foram descritas no Brasil, baseada em uma série de diferentes clones diferenciadores. Fundamentado nas reações de 11 clones diferenciadores já conhecidos na literatura (MDF 180, FX 3844, FX 985, FX 4098, FX 2261, FX 2804, FX
3899, IAN 6158, IAN 3087, IAN 717 e PA 31), contendo as espécies Hevea brasiliensis, Hevea benthamiana e Hevea pauciflora, realizou-se uma análise de agrupamento para os dados binários referente à virulência da doença utilizando o método de Jaccard. A análise de agrupamentos (cluster analysis) foi feita pelo método do centróide. Os resultados obtidos indicam a existência de 53 raças diferentes desse patógeno no Brasil.

Palavras-chave: Seringueira, mal da folha, clone diferenciadores, técnica de análise multivariada.

The rubber tree has its origin in the Amazon region; however, this species shows good plasticity and high adaptability to the most changeable environments (9). It was introduced to Oriental countries (Sri Lanka, Singapore and Malaysia), where the climate is very similar to that in its country of origin, and has presented good development, reaching greater productivity levels, since the pathogen of leaf blight is absent. Currently, more than $90 \%$ global rubber production originates in these countries $(10,6)$.

In Brazil, the biggest obstacle to the expansion of rubber tree plantation is the high incidence rate of leaf blight (Microcyclus ulei). This disease affects young leaves of rubber trees, causing premature fall and debilitating the plant after successive attacks of this disease $(13,7)$.

Strategies to address this problem include obtaining and planting productive cultivars that are resistant to the pathogen, and/or planting in regions where the climate conditions limit or reduce the development of M. ulei, i.e. escape regions like the Highlands of São Paulo. Due to the high adaptation capacity of the fungus, symptoms of this disease have already been reported in clonal gardens and greenhouses $(6,19)$.

When the pathogen interacts with a plant, injuries are expected to appear, initiating the infection cycle (1). Resistance is associated with lesion size, reduced sporulation and fungal latent period on the leaves (3). Sporulation is also considered a sensitive test for differentiating the pathogen race $(6,19,20)$.

There are two types of resistance: vertical resistance (monogenic) which is expressed against some races of the pathogen and is qualitative since it is present or absent, with very few exceptions; and horizontal resistance (polygenic) - which is uniformly efficient against all races of the pathogen and is quantitative in inheritance and effects, which can manifest between a minimum and a maximum degree $(1,20,23,21)$.

However, physiological specializations and adaptations were found for different populations of the pathogen that were tested in both susceptible and resistant clones. Several authors reported virulence of isolates through the pathogen-host interaction, leading to a hypersensitivity reaction until death, which shows the adaptation power of the pathogen and makes more complicated to obtain clones with durable resistance $(17,22)$.

Several authors expressed concern about the reactions of clones to different pathogen inocula (20). Lanford (14) began to distinguishing the aggressiveness of a new race of $M$. ulei attacking resistant clones such as F 409 and F 1619, and progenies of clone F 4542. Langdon (15) verified that isolates from Costa Rica were more aggressive than isolates from Guatemala since the former attacked and sporulated in germplasm of F 4542 clones, being named race 2, while isolates from Guatemala were named race 1 . Miller (18) described two new races 
of M. ulei through different rubber tree clones: races 3 and 4, isolates from Guatemala and Costa Rica, which did not attack progenies from Madre de Dios but attacked F 4542.

Gonçalves (8) evaluated the resistance of rubber tree clones in the field in five different regions to determine the progenies with higher resistance to leaf blight. Brasil Sudhevea (2) described two new races of M. ulei, $4 \mathrm{~b}$ and $4 \mathrm{c}$, and divided them into parental groups as regards the disease attack on $H$. brasiliensis and $H$. benthamiana hybrids. Chee et al. (4) used disks of sick leaves to identify more three new races and determined that races $4 \mathrm{~b}$ and $4 \mathrm{c}$ should be denominated races 5 and 6 , indicating the existence of 5 pathogenic races and one race that has not been pathogenic so far.

Junqueira et al. (12) worked with 16 isolates of M. ulei from Brazil, using 33 clones of rubber tree as differential clones, and suggested 15 new pathogen races, besides the wild avirulent race. They found five races attacking F 4542 but not sporulating in Fx 985 and 180 MDF (Group I); another group attacked and sporulated in most progenies of H. brasiliensis (Group II). A third group was proposed, which sporulated in most progenies of F 4542 and in some progenies of H. brasiliensis; this third group was added to that proposed by Brasil Sudhevea (2), as it attacked hybrids of $H$. brasiliensis and $H$. benthamiana (Group III), but groups were not completed for all existing races. The authors concluded that the isolates showed great physiological variability and virulence varied with the used clone, but a few isolates behaved similarly to races 1, 2, 3 and 4 proposed by Miller (18).

Mattos et al. (17) used 50 isolates from the pathogen obtained at the southeast of Bahia State and tested them in 12 differential clones of rubber tree, obtaining 36 races of $M$. ulei. Of these 36 virulence patterns, 21 showed virulence in more than nine of the 12 tested clones, but none attacked isolates and sporulated in all tested clones. Those researchers used three species among the tested clones of rubber tree with $H$. brasiliensis, $H$. benthamiana and $H$. pauciflora to differentiate races, adapting and employing the scale of grades proposed by Junqueira et al. (12).

Several races of M. ulei have been described in Brazil based on a number of different clones of rubber tree. However, to the present moment, the number of races present on Brazil is unknown.

Thus, this paper aimed to perform inoculation tests under controlled environments in monocyclic studies, comparing them to the reactions reported by Chee et al. (4), Junqueira et al. (12) and Mattos et al. (17), and to propose a minimal quantity of races, the race group and the base races of differential clones of $M$. ulei existing in Brazil.

\section{MATERIAL AND METHODS}

Data were collected from Umuarama Farm, in the region of Registro City - São Paulo State, at an average altitude of $52 \mathrm{~m}$, latitude $24^{\circ} 24^{\prime} \mathrm{S}$ and longitude $47^{\circ} 48^{\prime} \mathrm{W}$, where average annual precipitation is 1627 $\mathrm{mm}$ and average temperature is $22^{\circ} \mathrm{C}$. Rubber trees were permanently planted in monoclonal blocks, scattered all over the property.

According to the method of Junqueira et al. (12), fungal isolates stemmed from coriaceous lesions on PDA in test tubes. Small colonies were obtained and macerated on the edge of the tube with a glass rod by adding $5 \mathrm{~mL}$ sterile distilled water. The product of the steeping was placed in Erlenmeyer flasks, each of which contained $20 \mathrm{~mL}$ culture medium called M4 (12), $6 \mathrm{~g}$ neopeptone compound, $10 \mathrm{~g}$ sucrose, $20 \mathrm{~g}$ agar, $2 \mathrm{~g} \mathrm{KH}_{2} \mathrm{PO}_{4}, 1 \mathrm{~g} \mathrm{MgSO}_{4} .7 \mathrm{H}_{2} \mathrm{O}, 1 \mathrm{~mL}$ chloramphenicol $15 \%$ and distilled water to 1 liter volume; the inocula were spread on the agar surface and incubated at $24^{\circ} \mathrm{C} \pm 1^{\circ} \mathrm{C}$ in the dark. After 15 days, $12 / 12 \mathrm{~h}$ photoperiod was initiated for 2-3 days for inoculum preparation. After this time, $10 \mathrm{~mL}$ sterile distilled water was added to each Erlenmeyer flask and colonies were prepared by scraping with a sterile brush.

Inoculations were performed by spraying the abbatial surface of 6-8-day-old leaflets, corresponding to stages B1 and B2 described by Hallé et al. (11), with a conidial suspension obtained from six cultures of the fungus originated from Vale do Ribeira. Concentration varied with the age of the culture $\left(2 \times 10^{5}\right.$ for 10 -12-day-old cultures; $3 \times 10^{5}$ for 12-16-day-old cultures, and $5 \times 10^{5}$ for older cultures) maintained in M4 medium; each isolate was inoculated at least three times until the emergence of leaves.

The rubber tree cultivars used as differential clones in this study were MDF 180, Fx 3844, Fx 985, Fx 4098, Fx 2261, Fx 2804, Fx 3899, IAN 6158, IAN 3087 and IAN 717 grafted onto genetically heterogeneous rootstock grown in plastic bags containing $10 \mathrm{~kg}$ substrate, $30 \%$ tanned manure and $70 \%$ soil. Seedlings in the third leaf emergence were kept in a greenhouse belonging to the former «Centro Nacional de Pesquisa de Seringueira e Dendê», currently «Núcleos de

Table 1. Classification of lesions (adapted grade) according to spore number, lesion type and size, and scale of grades (12).

\begin{tabular}{|c|c|c|c|c|c|}
\hline Note & Lesion type & Lesion size & $\begin{array}{c}\text { Spores } \\
\text { (conidia/cm² damaged surface) }\end{array}$ & & $\begin{array}{c}\text { Adapted Grade } \\
\text { (binary data) }\end{array}$ \\
\hline 0 & $\begin{array}{l}\text { Chlorotic / necrotic } \\
\text { spots }\end{array}$ & $<1 \mathrm{~mm}$ & \multirow{3}{*}{\multicolumn{2}{|c|}{ Without spores }} & \multirow{3}{*}{$\begin{array}{c}0 \\
\text { Resistant }\end{array}$} \\
\hline 2 & \multirow{6}{*}{$\begin{array}{l}\text { Lesions with } \\
\text { necrotic center }\end{array}$} & 1 to $2 \mathrm{~mm}$ & & & \\
\hline 3 & & $>2 \mathrm{~mm}$ & & & \\
\hline 6 & & $>3 \mathrm{~mm}$ or & from 1,000 to 30,000 or & \multirow{4}{*}{$\begin{array}{l}\text { With } \\
\text { spores }\end{array}$} & \multirow{4}{*}{$\begin{array}{c}1 \\
\text { Susceptible }\end{array}$} \\
\hline 0 & & 1 to $2 \mathrm{~mm}$ & 30,000 to 70,000 & & \\
\hline 7 & & 2 to $2.5 \mathrm{~cm}^{2}$ & 70,000 a 400,000 & & \\
\hline 8 & & 2 to $2.5 \mathrm{~cm}^{2}$ & $>400,000$ & & \\
\hline
\end{tabular}

Source: Adapted from Junqueira et al. (12). 
Apoio à Pesquisa e Transferência de Tecnologias» (NAPT), Eastern Amazon Embrapa.

Following inoculation, plants were exposed to a humid chamber $(97 \% \mathrm{RH})$ at $24^{\circ} \mathrm{C}$ for 12 hours light at 2000 lux and 12 hours dark. After this period, plants were removed from the moist chamber and kept for eight days in a growth chamber at $24^{\circ} \mathrm{C}$ and relative humidity ranging from 80 to $85 \%$; then, they were finally transferred to a greenhouse at $26-30^{\circ} \mathrm{C}$ and $78-83 \%$ humidity. Evaluations were performed by determining the latent period: days from inoculation to the onset of $50 \%$ spores $(21)$.

After fifteen days of inoculation, the number of injuries was counted for every $8 \mathrm{~cm}^{2}$ leaf surface, and the average diameter of lesions and the sporulation intensity were evaluated. Lesions were classified based on a scale of grades and each reaction type - Table 1 (12).

Junqueira et al. (12) worked with M. ulei races from all over Brazil, corresponding to letters A to $\mathrm{O}$ in Figure 1. Mattos et al. (17) worked with isolates from the region of Ituberá City at Michelin Plantations - Bahia State (letter B in Figure 1). Chee et al. (4) also worked with isolates from Bahia State but from a different region of Una City (letter $\mathrm{C}$ in Figure 1). In the present study, isolates were obtained from Vale do Ribeira, Registro City - São Paulo State (letter A in Figure 1).

First, the scale of grades used by Junqueira et al. (12) was adapted to a binary scale (zero and one), as shown in Table 1. The following codification was used: zero for resistant reactions (without sporulation) and one for susceptible reactions (with sporulation). Wild isolates without signs of virulence were then removed (HM1_NTVJ_1, 1 CHEE and 5_CHEE) for the use of Jaccard's method. Cluster analysis was done based on the centroid method. Statistical procedures were conducted by using PROC DISTANCE, TREE and CLUSTER in SAS (Statistical Analysis System, version 9.2).

Reactions of the 11 differential clones described above belonging to the species Hevea brasiliensis, Hevea benthamiana and Hevea pauciflora were compared. Analysis of binary group data referring to the pathogen virulence was carried out according to Jaccard's method (5), as a sensitive test for the differentiation of pathogen races $3,6,19$.

\section{RESULTS}

Six M. ulei isolates were obtained from the farm Umuarama for stemming analysis; they were named MU_01, MU_02, MU_03, MU_04, MU_05 and MU_06. The type of reaction was classified based on the caused injury, as shown in Table 2.

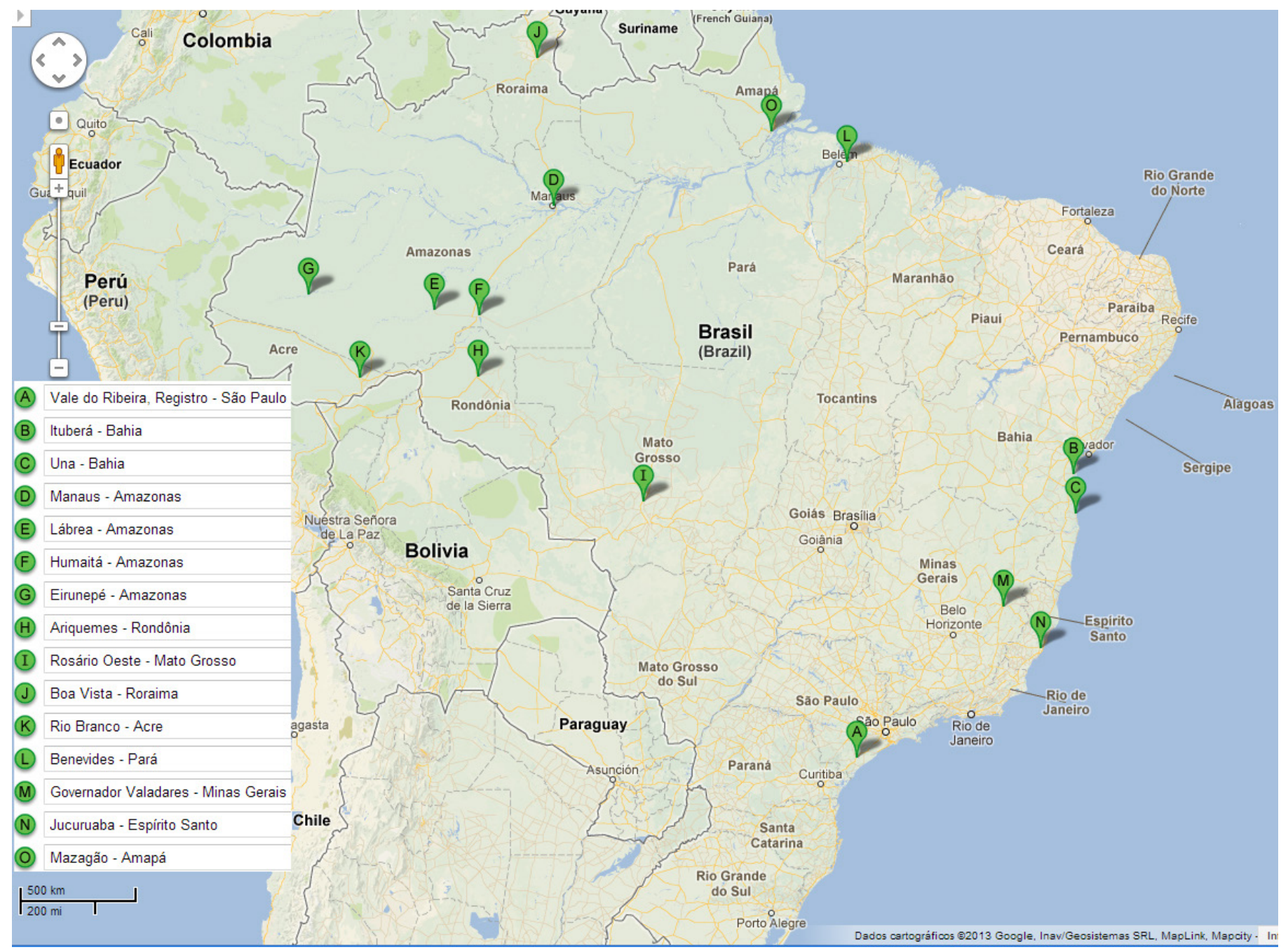

Figure 1. Places of M. ulei isolates collection in Brazil by Chee et al. (4), Junqueira et al. (12), Furtado in 1990 and Mattos et al. (17). Source: Adapted from Google Maps ${ }^{\circledR}$ (2013). 
Table 2. Resistance and susceptibility reaction according to differential clones of rubber tree and isolates of M. ulei from Vale do Ribeira-São Paulo State.

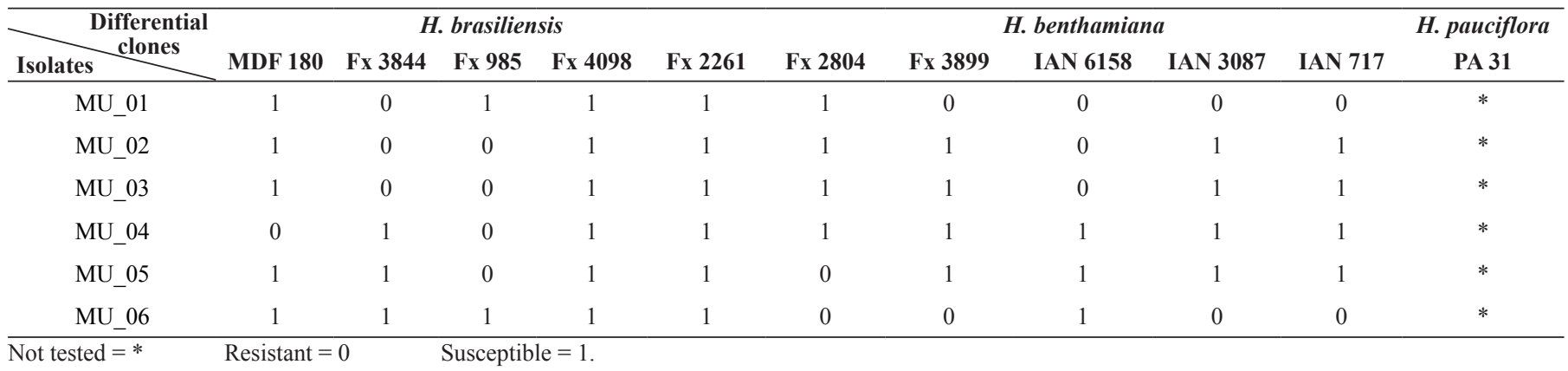

Jaccard's index of similarity has been used to group the studied ecological species (5). In this study, this technique was used to group isolated races of $M$. ulei with specific differential clones of rubber tree base.

Grouping could only be performed after substituting the nominal scale of grades used by the cited authors and proposed by Junqueira et al. (12) for the ordinal scale (binary) - Table 1. Those authors also worked over different times with the same differential clones of rubber tree base as the ones used in this study (Table 2), keeping a basis for differential races of $M$. ulei (Table 3).

After analyzing the data from this study and the results of the cited papers, comparisons between the used differential clones could be made

Table 3. Resistance and susceptibility reaction according to differential clones of rubber tree and isolates of $M$. ulei of the cited papers.

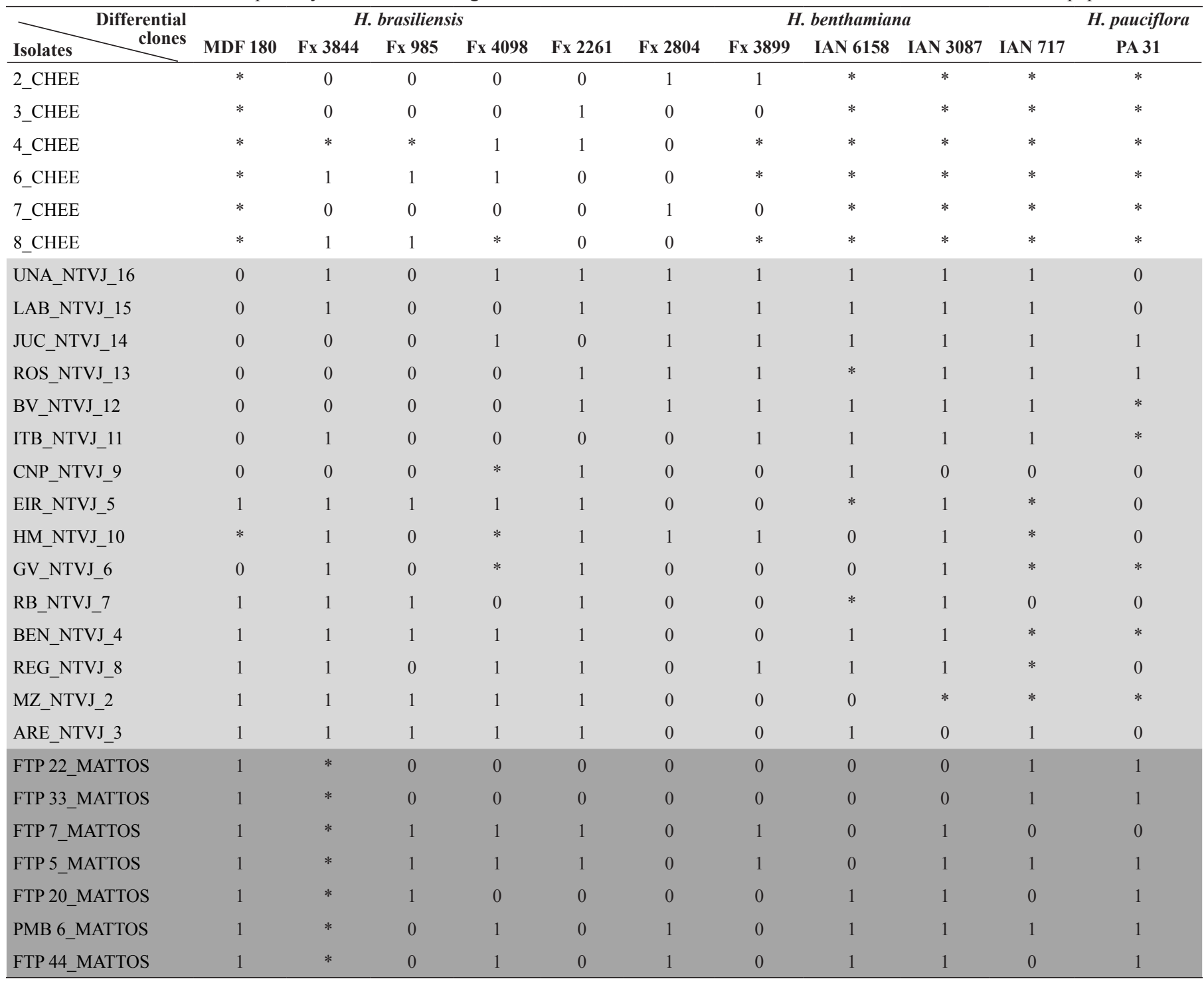

continua.,. 
Table 3. Continuação

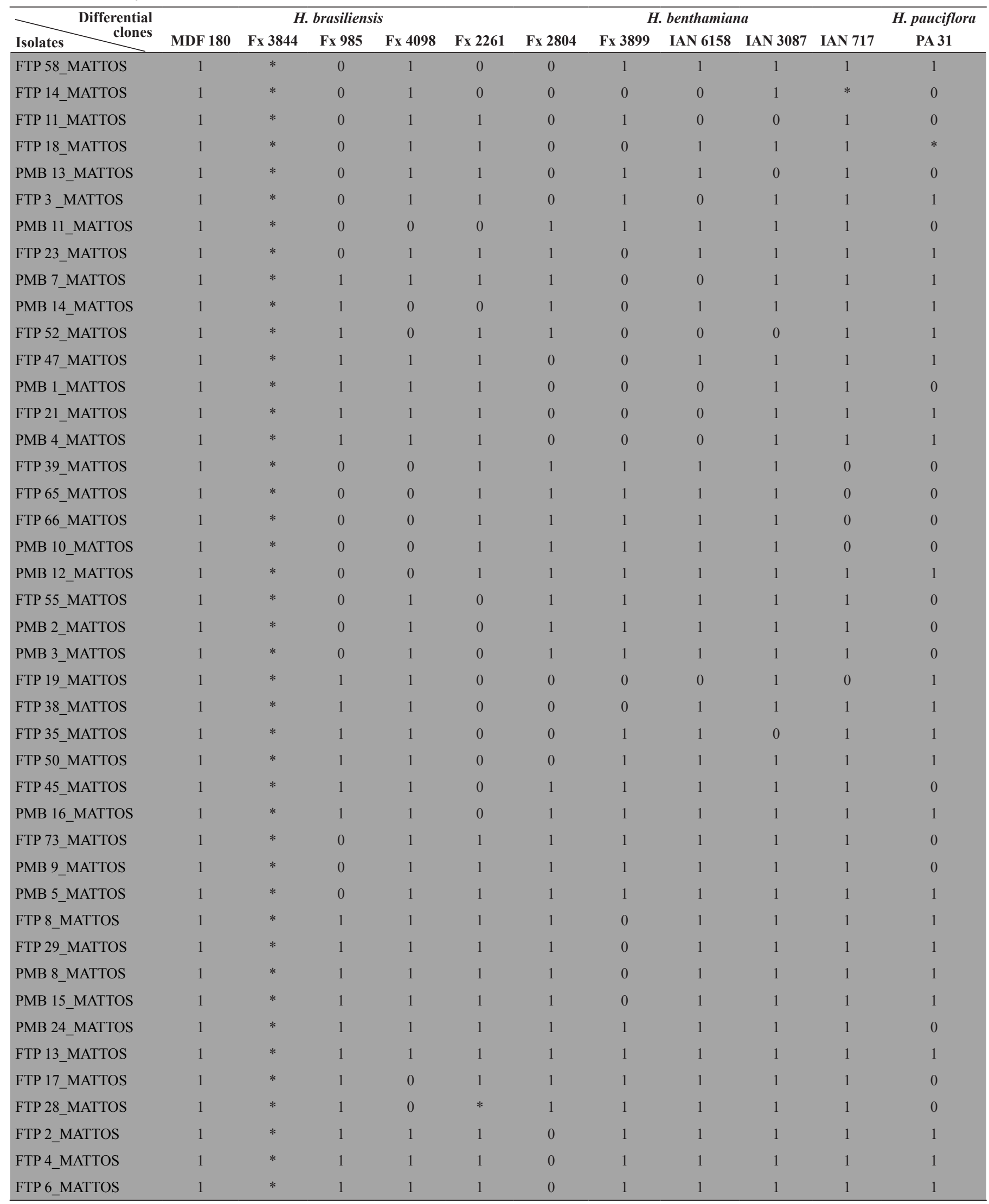

Not tested $=*$

Resistant $=0$

Susceptible $=1$. Source: Adapted from Chee et al., (4); Junqueira et al. (12) and Mattos et al. (17). 


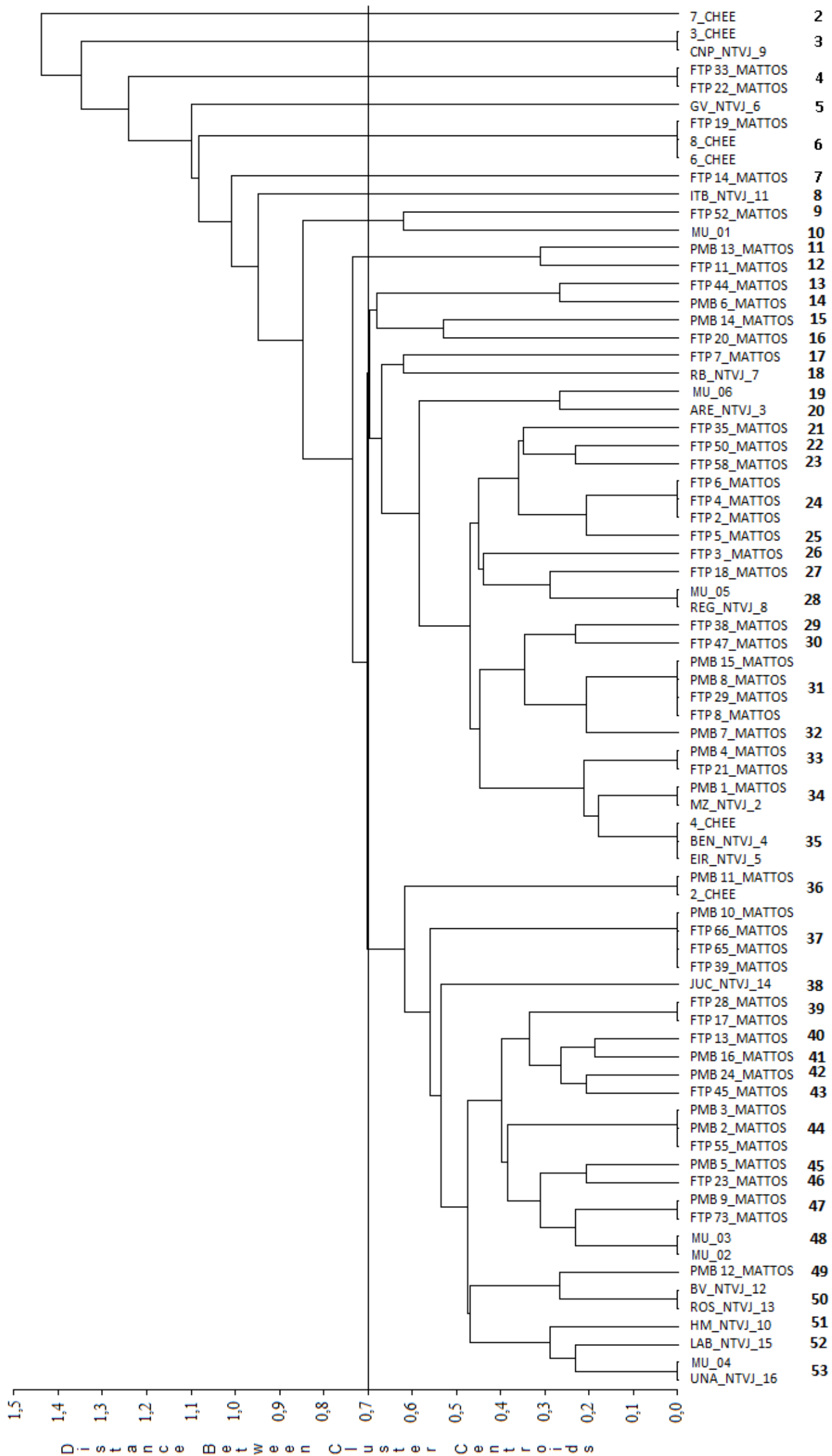

Figure 2. Dendrogram of Microcyclus ulei races described in Brazil, containing 53 races (except for the non-virulent wild one), thus numbering starts from the number 2 . 
inoculation tests under controlled environment in monocyclic studies and currently by analyzing the data in this paper. The second one was tested 10 years before with the same differential clones (12).

Tests were performed with 14 different clones, adding PFB 5, IAN 2909 and CNS AM 7907 to the 11 differential clones of this paper. Then, 13 clones were used, adding PFB 5 and IAN 2909. Subsequently, 12 clones were tested by adding only IAN 2909. Finally, 10 clones were tested, Fx 3844, Fx 985, Fx 4098, Fx 2261, Fx 2804, Fx 3899, IAN 6158, IAN 3087, IAN 2909 and PA 31. Other combinations of different clones were tested, but no combination reached the mark of 53 races, compared with the 11 differential clones proposed in this paper.

Analyzing M. ulei isolates from Vale do Ribeira proposed in this paper (Figure 2 and Table 3), three races of M. ulei can be clearly identified occurring only in this region, which means that races 10, 19 and 48 are considered new adapted races arising at Vale do Ribeira. According to the dendrogram of races (Figure 2), race 53, the isolate MU_04, comes from Vale do Ribeira, while the isolate reported by Junqueira et al. (12) comes from the region of Una, Bahia State. Therefore, it is not clear whether the isolate of race 53 came by means of atmospheric winds or by plant contamination by the fungus that came to this region.

Most clones are known to behave differently according to the environment where they are cultivated, showing low genetic homeostasis (Nascimento, 1983 apud Macedo et al. (16)). Some examples can be cited: Clone MDF 180, highly susceptible to the isolates from Amazonas, Bahia, Espírito Santo, Mato Grosso, Minas Gerais and Roraima States, Junqueira et al. (12); Clone Fx 3899, well cultivated in Acre, Rondônia and Amazonas, it was considered of high resistance in Pará and, subsequently, started to behave as highly susceptible; and clone Fx 2261, it shows good performance in the state of Bahia but very poor results in the state of Amazonas
(Gomes et al. 1983 apud Furtado et al. (6)).

At Vale do Ribeira, homogeneity is greater when the races of most resistant cultivars arising in this region are compared, since when one cultivar is resistant to two races it is susceptible to another one. For example, Fx 3844 and IAN 6158 are resistant to races 10 and 48 but susceptible to race 19; Fx 3899, IAN 3087 and IAN 717 are resistant to races 10 and 19 but susceptible to race 48; it shows high adaptation and resistance break of emerging new races.

As shown in Table 4, possible differential clones of M. ulei isolates were grouped into races according to cluster analysis. The separation of races (Figure 2 and Table 4) proposed by Miller (18) and continued by Chee et al. (4) becomes compromised, as observed by Junqueira et al. (12). All isolates that attacked and sporulated in clone Fx 2261 and did not sporulate in clone Fx 2804 but were virulent for clone Fx 3899 had the F 4542 gene.

As the data of studies complement themselves (Table 4), the race separation system proposed by Miller (18) and Chee et al. (4) becomes compromised, not only showing the very high variability of the pathogen but also the great adaptability to the clones said to be resistant and utilized to differentiate the races in the first studies.

Therefore, according to Table 4 , isolates were separated from races 1 to 53, where 1 is the wild non-virulent isolate. According to the definitions of M. ulei physiological race groups proposed by Brasil Sudhevea (2), isolates from races $36,37,38,39,40,41,42,43,44$, $45,47,48,49,50,51,52$ and 53 are virulent to clones Fx 2804 and Fx 3899, bearers of the F 4542 gene, forming group I with a total of 17 races. However, none of these isolates were non-virulent to clones Fx 985 and MDF 180, proposed by Junqueira et al. (12). According to Brasil Sudhevea (2), this group I does not attack F 409 hybrids $(H$. brasiliensis), and its resistance source is on hybrids of $H$. brasiliensis.

Races 3, 4, 5, 6, 7, 16, 18, 19, 20, 27, 29, 30, 33, 34 and 35 are not virulent to clones Fx 2804 and Fx 3899, which means they do

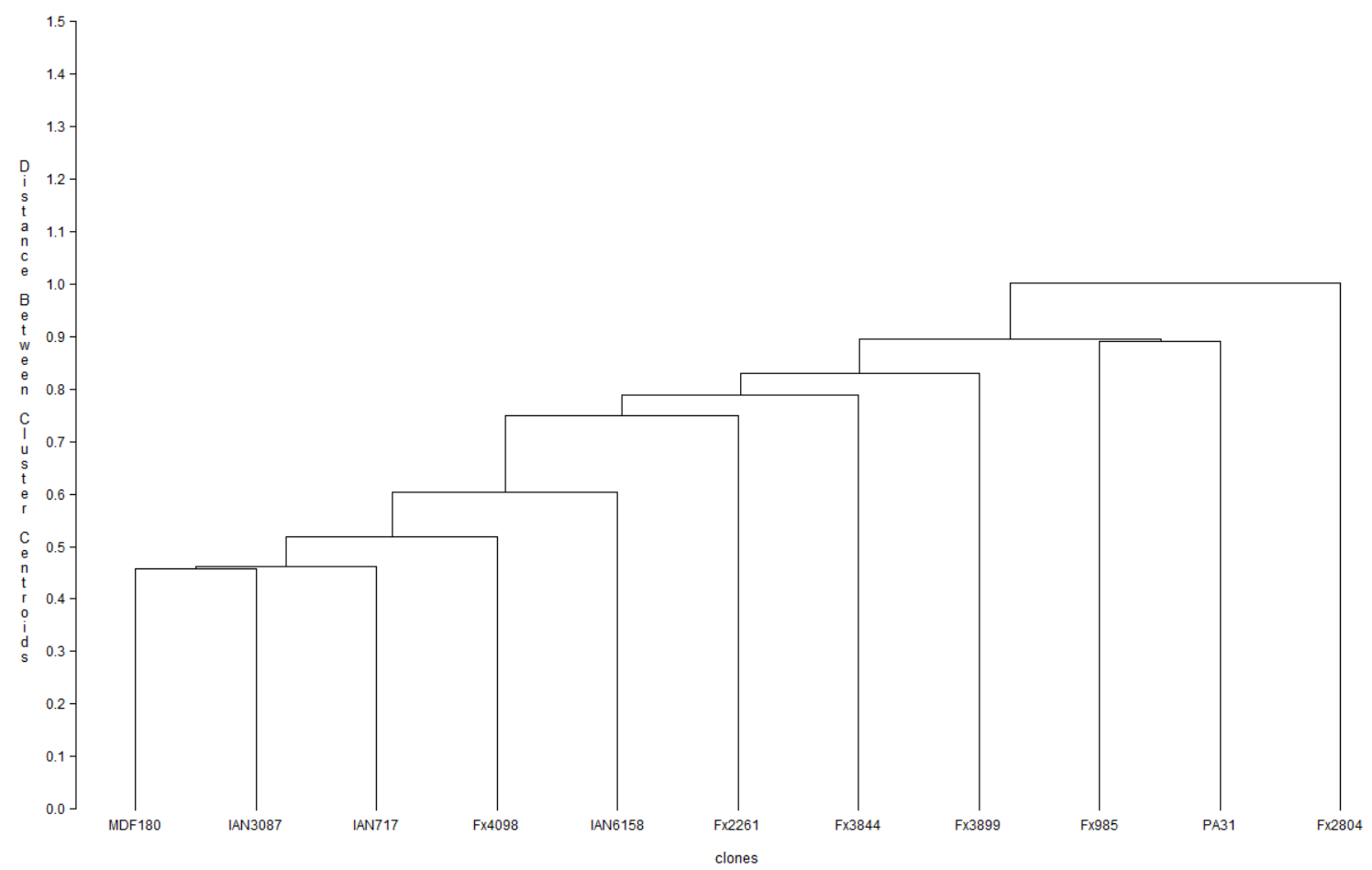

Figure 3. Dendrogram of differential clones used in this study and those used by Chee et al. (4), Junqueira et al. (12) and Mattos et al. (17), grouped in relation to the used isolates. 
Table 4. Susceptibility and resistance reaction according to differential clones of rubber tree and isolates of $M$. ulei grouped according to the races show in Figure 2.

\begin{tabular}{|c|c|c|c|c|c|c|c|c|c|c|c|c|}
\hline \multirow{2}{*}{$\underbrace{\mathrm{D}}_{\text {Isolates }}$} & \multicolumn{5}{|c|}{ H. brasiliensis } & \multicolumn{5}{|c|}{ H. benthamiana } & \multirow{2}{*}{$\begin{array}{c}\text { H. pauciflora } \\
\text { PA } 31\end{array}$} & \multirow[b]{2}{*}{ Races } \\
\hline & MDF 180 & Fx 3844 & Fx 985 & Fx 4098 & Fx 2261 & Fx 2804 & Fx 3899 & IAN 6158 & IAN 3087 & IAN 717 & & \\
\hline HM1_NTVJ_1 & $*$ & 0 & 0 & 0 & 0 & 0 & 0 & 0 & 0 & $*$ & $*$ & \\
\hline 1_CHEE & $*$ & 0 & 0 & 0 & 0 & 0 & 0 & $*$ & $*$ & $*$ & $*$ & 1 \\
\hline 5_CHEE & $*$ & 0 & 0 & 0 & 0 & 0 & $*$ & $*$ & $*$ & $*$ & $*$ & \\
\hline 7_CHEE & $*$ & 0 & 0 & 0 & 0 & 1 & 0 & $*$ & $*$ & $*$ & $*$ & 2 \\
\hline CNP_NTVJ_9 & 0 & 0 & 0 & $*$ & 1 & 0 & 0 & 1 & 0 & 0 & 0 & 3 \\
\hline FTP 33_MATTOS & 1 & $*$ & 0 & 0 & 0 & 0 & 0 & 0 & 0 & 1 & 1 & 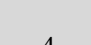 \\
\hline FTP 22_MATTOS & 1 & $*$ & 0 & 0 & 0 & 0 & 0 & 0 & 0 & 1 & 1 & 4 \\
\hline GV_NTVJ_6 & 0 & 1 & 0 & $*$ & 1 & 0 & 0 & 0 & 1 & $*$ & $*$ & 5 \\
\hline FTP 14_MATTOS & 1 & $*$ & 0 & 1 & 0 & 0 & 0 & 0 & 1 & $*$ & 0 & 7 \\
\hline ITB_NTVJ_11 & 0 & 1 & 0 & 0 & 0 & 0 & 1 & 1 & 1 & 1 & $*$ & 8 \\
\hline FTP 52_MATTOS & 1 & $*$ & 1 & 0 & 1 & 1 & 0 & 0 & 0 & 1 & 1 & 9 \\
\hline MU_01 & 1 & 0 & 1 & 1 & 1 & 1 & 0 & 0 & 0 & 0 & * & 10 \\
\hline PMB 13_MATTOS & 1 & $*$ & 0 & 1 & 1 & 0 & 1 & 1 & 0 & 1 & 0 & 11 \\
\hline FTP 11_MATTOS & 1 & $*$ & 0 & 1 & 1 & 0 & 1 & 0 & 0 & 1 & 0 & 12 \\
\hline FTP 44_MATTOS & 1 & $*$ & 0 & 1 & 0 & 1 & 0 & 1 & 1 & 0 & 1 & 13 \\
\hline PMB 6_MATTOS & 1 & $*$ & 0 & 1 & 0 & 1 & 0 & 1 & 1 & 1 & 1 & 14 \\
\hline PMB 14_MATTOS & 1 & $*$ & 1 & 0 & 0 & 1 & 0 & 1 & 1 & 1 & 1 & 15 \\
\hline FTP 50_MATTOS & 1 & $*$ & 1 & 1 & 0 & 0 & 1 & 1 & 1 & 1 & 1 & 22 \\
\hline FTP 58_MATTOS & 1 & $*$ & 0 & 1 & 0 & 0 & 1 & 1 & 1 & 1 & 1 & 23 \\
\hline FTP 6_MATTOS & 1 & $*$ & 1 & 1 & 1 & 0 & 1 & 1 & 1 & 1 & 1 & \\
\hline FTP 4_MATTOS & 1 & $*$ & 1 & 1 & 1 & 0 & 1 & 1 & 1 & 1 & 1 & 24 \\
\hline FTP 2_MATTOS & 1 & $*$ & 1 & 1 & 1 & 0 & 1 & 1 & 1 & 1 & 1 & \\
\hline FTP 5_MATTOS & 1 & $*$ & 1 & 1 & 1 & 0 & 1 & 0 & 1 & 1 & 1 & 25 \\
\hline FTP 3_MATTOS & 1 & $*$ & 0 & 1 & 1 & 0 & 1 & 0 & 1 & 1 & 1 & 26 \\
\hline FTP 18_MATTOS & 1 & * & 0 & 1 & 1 & 0 & 0 & 1 & 1 & 1 & $*$ & 27 \\
\hline MU_05 & 1 & 1 & 0 & 1 & 1 & 0 & 1 & 1 & 1 & 1 & * & 28 \\
\hline REG_NTVJ_8 & 1 & 1 & 0 & 1 & 1 & 0 & 1 & 1 & 1 & $*$ & 0 & \\
\hline FTP 38_MATTOS & 1 & $*$ & 1 & 1 & 0 & 0 & 0 & 1 & 1 & 1 & 1 & 29 \\
\hline FTP 47_MATTOS & 1 & * & 1 & 1 & 1 & 0 & 0 & 1 & 1 & 1 & 1 & 30 \\
\hline PMB 15_MATTOS & 1 & $*$ & 1 & 1 & 1 & 1 & 0 & 1 & 1 & 1 & 1 & \\
\hline PMB 8_MATTOS & 1 & $*$ & 1 & 1 & 1 & 1 & 0 & 1 & 1 & 1 & 1 & 31 \\
\hline FTP 29_MATTOS & 1 & $*$ & 1 & 1 & 1 & 1 & 0 & 1 & 1 & 1 & 1 & 31 \\
\hline FTP 8_MATTOS & 1 & $*$ & 1 & 1 & 1 & 1 & 0 & 1 & 1 & 1 & 1 & \\
\hline
\end{tabular}


Table 4. Continuação

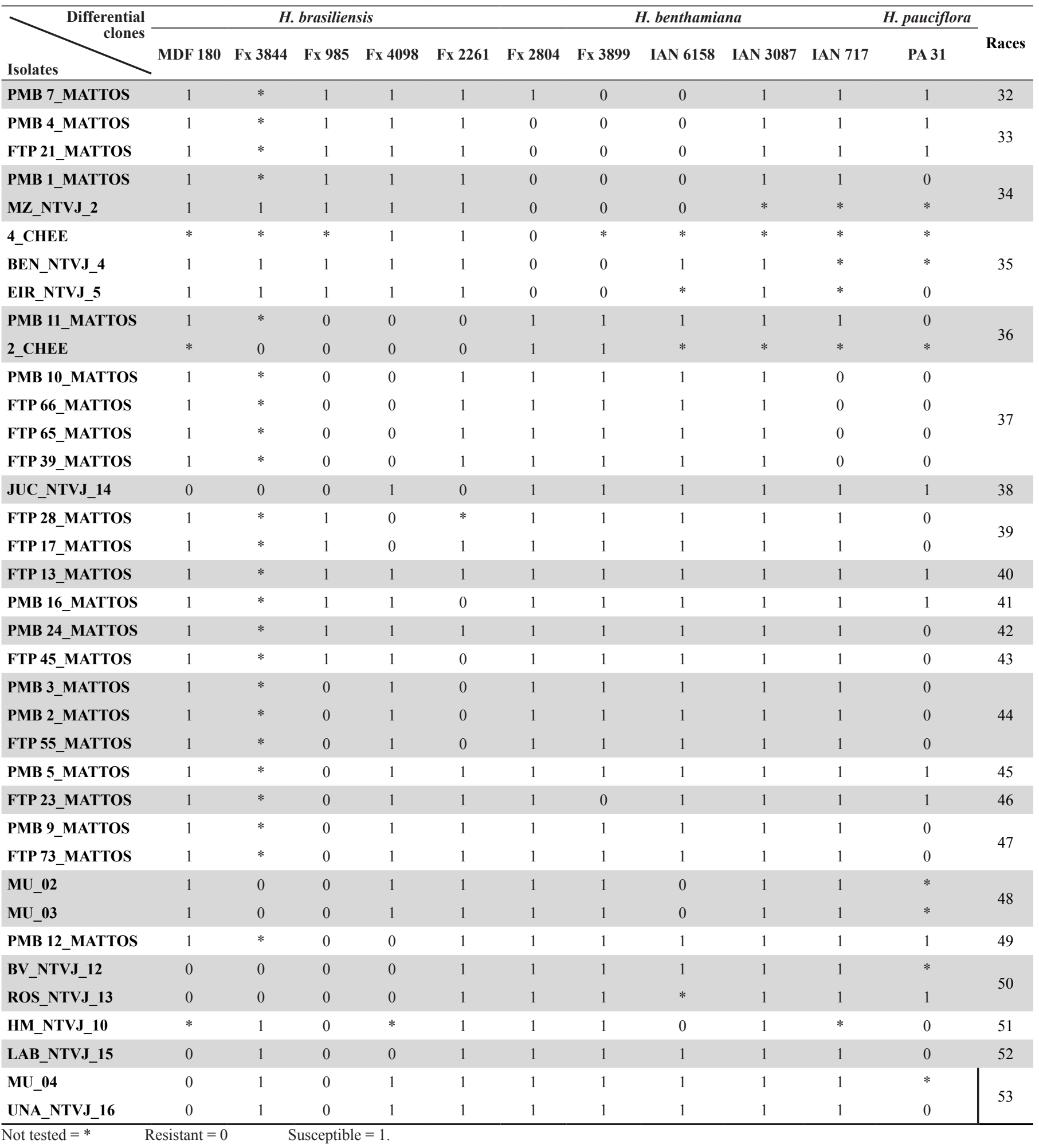

and the number of M. ulei races existing in Brazil could be quantified; they are represented on the dendrogram in Figure 2.

\section{DISCUSSION}

Several M. ulei races were described in Brazil based on a series of differential clones, but the number of races present in Brazil is still unknown.

After reviewing the obtained dendrogram (Figure 2), 52 races of the fungus could be classified, which, added to the wild avirulent isolates reported by Chee et al. (4) and by Junqueira et al. (12), leads to 53 present races.

In fact, isolates MU_05 and REG_NTVJ_8 correspond to the same races (number 28 - Figure 2). The first one was obtained by Furtado in 1990 in Vale do Ribeira - Sao Paulo State by means of 
not attack hybrids with the clone gene F 4542, forming group II with 15 races.

Therefore, group III proposed by Junqueira et al. (12) features resistance sources in both $H$. brasiliensis and $H$. benthamiana (bearers of the F4542 genes). This group III, composed of races 2, 8, 9, 10, 11, $12,13,14,15,17,21,22,23,24,25,26,28,31$ and 32 , is virulent to one F 4542 hybrid but not for the other. Some races had resistance to $H$. brasiliensis hybrids, while others were very virulent, but it is the largest group, with a total of 19 races.

The concepts of groups proposed by both Brasil Sudhevea (2) and Junqueira et al. (12) were compromised when analyzed together with the isolates reported by Mattos et al. (17), since the latter contains an isolate that attacks all other clones, race 40 , and another one, race 31 , which attacks all other clones except Fx 3899, but race 24 did not attack Fx 2804 (bearer of the resistance gene from hybrid F 4542). Race 45 did not attack Fx 985 (F 409 gene). Race 42 did not attack PA 31 (H. pauciflora). Race 41 did not attack Fx 2261. Moreover, all isolates reported by Mattos et al. (17) attacked MDF 180 clone (basis of $H$. brasiliensis hybrid resistance), compromising the group concept proposed by those authors.

In this study, the cut of 0.7 (usual in cluster analysis) was proposed for the scale of distance between centroids (standard in cluster analysis) of the facts analyzed from the 53 races to define new groups. Similarly, 13 groups of M. ulei physiological races were obtained.

New groups were proposed, followed by their respective races within parentheses. Group 1 (1) - the non-virulent wild race; group 2 (2) - only attacks Fx 2804; group 3 (3) - only attacks Fx 2261 and IAN 6158; group 4 (4) - only attacks MDF 180, IAN 717 and PA 31; group 5 (5) - attacks Fx 3844, Fx 2261 and IAN 3087; group 6 (6) - attacks MDF 180, Fx 3844, Fx 985, Fx 4098, IAN 3087 and PA31; group 7 (7) - attacks MDF 180, Fx 4098 and IAN 3087; group 8 (8) - attacks Fx 3844, Fx 3899, IAN 6158, IAN 3087 and IAN 717; group 9 (9 and 10) - attacks MDF 180, Fx 985, Fx 2261 and Fx 2804 but does not attack Fx 3899, IAN 6158 and IAN 3087; group 10 (11 and 12) - attacks MDF 180, Fx 4098, Fx 2261, Fx 3899 and IAN 717 but does not attack Fx 985, Fx 2804, IAN 3087 and PA 31; group 11 (13, 14, 15 and 16) - attacks MDF 180, IAN 6158, IAN 3087 and PA 31, but does not attack Fx 2261 and Fx 3899; group 12 (17 up to 35) - attacks MDF 180 and Fx 4098; group 13 (36 up to 53) -overlaps with a group proposed by Brasil Sudhevea (2), but with the addition of race 46 does not attack clone Fx 3899. This group 13 attacks Fx 2804 and IAN 3087. All group concept for M. ulei physiological races can be very useful to separate commercial clones according to the regions where the groups may act.

As shown in Figure 3, two groups of differential clones were determined, group 1, including clones MDF 180, IAN 3087, IAN 717, Fx 4098, IAN 6158 and Fx 2261; and group 2, with clones Fx 3899, Fx 985, PA 31 and Fx 2804. Clone Fx 3844 stayed right in the center of the dendrogram. Comparison of Table 4 with Figure 3 and their groups indicated that group 1 has clones with little resistance, to at most $33 \%$, and high susceptibility, over $61 \%$, reaching a maximum at $76 \%$ (MDF 180), followed by $75 \%$ (IAN 3087) and 65\% (IAN 717, Fx 4098 and Fx 2261).

Group 2 has resistance higher than 34\%, reaching a maximum of $54 \%$ resistance (clone Fx 985) and susceptibility below 52\%, clone PA 31 was the unique hybrid of the species $H$. pauciflora. This was the species of group 2 which had the lowest resistance, $34 \%$, and susceptibility of $40 \%$, but there is still a margin testing, because this group has the highest percentage of non-tested isolates, reaching $26 \%$. Clone Fx 3844, staying right in the center of the dendrogram, was not tested too much, with 64\%, as it was not used by Mattos et al. (17).

Therefore, by using $H$. brasiliensis, $H$. benthamiana bases and $H$. pauciflora, all isolates can be tested, keeping or even raising the number of species existing in Brazil, in addition to standardizing future studies and comparing them to existing ones.

The present study and the studies developed by Chee et al. (4), Junqueira et al. (12) and Mattos et al. (17) for the analysis of $M$. $u l e i$ variability showed high adaptability and great diversity of the fungus. Publications have indicated race variability, and for tests not performed due to lack of differential clones in common, a minimum quantity of 53 races of Microcyclus ulei exists in Brazil.

\section{REFERENCES}

1. Bergamin Filho, A.; Amorim, L. Epidemiologia comparativa entre os patossistemas temperado e tropical: conseqüências para a resistência a fungicidas. Fitopatologia Brasileira, [online], v.26, p.119-127, 2001.

2. Brasil Sudhevea. Pesquisa Fitopatológica: Pesquisas e experimentação realizadas com a seringueira. In: Plano Nacional da Borracha. Rio de Janeiro: Ministério da Indústria e Comércio; Superintendência da Borracha, 1971. s.i. anexo XI, p.35-43.

3. Chee, K.H. Factors affecting discharge, germination and viability of spores of Microcyclus ulei. Transactions of the British Mycological Society, London, UK, v.66, p.499-504, 1976.

4. Chee, K.H.; Zhang, K.M.; Darmono, T.W. The occurrence of eight species of Microcyclus ulei on Hevea rubber in Bahia State, Brazil. Journal of the British Mycological Society, London, UK, v.87, p.15-21, 1986.

5. Choi, S.S.; Cha, S.H.; Tappert, C.C. A survey of binary similarity and distance measures. Journal of Systemics, Cybernetics and Informatics, New York, US, v.8, p.43-48, 2010.

6. Furtado, E.L.; Menten, J.O.M.; Passos, J.R. Intensidade do mal das folhas em plantas jovens e adultas de seis clones de seringueira na região do Vale do Ribeira. Tropical Plant Pathology, Brasília, DF, v.33, n.2, p. 130-137, 2008.

7. GASPAROTTO, L.; FERREIRA, F.A. Doenças da seringueira. In: FERREIRA, F.A. Patologia florestal - principais doenças florestais no Brasil. Viçosa: Sociedade de Investigações Florestais, 1989. p.289-313.

8. Gonçalves, J.R.C. The resistance of Fx and IAN rubber clones to leaf diseases in Brazil. Tropical Agriculture, St. Augustine, Trinidad, v.45, p.331-336, 1968.

9. Gonçalves, P.S.; Cardoso, M.; Ortolani, A.A. Origem, variabilidade e domesticação da Hevea: uma revisão. Pesquisa Agropecuária Brasileira, Brasília, DF, v.25, n.2, p.135-156, 1990.

10. Gonçalves, P.S.; Paiva, J.R.; Souza, R.A. Retrospectiva e atualidade no melhoramento genético da seringueira (Hevea spp.) no Brasil e em países asiáticos. Manaus: EMBRAPA/CNPSD, 1983. 69p.

11. Hallé, F.; Oldeman, R.A.A.; Tomlinson, P.B. Tropical trees and forests: an architetural analysis. Berlin: Springer-Verlag, 1978.

12. Junqueira, N.T.V.; Chaves, G.M.; Zambolim, L.; Gasparotto, L.; Alfenas, A.C. Variabilidade fisiológica de Microcyclus ulei. Fitopatologia Braa sileira, Brasília, DF, v.11, p.823-833, 1986.

13. Langford, M.H. South American leaf bligth of Hevea rubber tree. Washington: USDA, 1945. (USDA Techinical Bulletin, 882).

14. Langford, M.H. A new strain of leaf blight on rubber trees in Costa Rica. Washington, D.C.: AID, 1960. 4p. Mimeografado.

15. Langdon, K.R. Relative resistance or susceptibility of several clones of Hevea brasiliensis $x$ H. benthamiana to two species of Dothidella ulei. Plant Disease Reporter, Saint Paul,Minnesota, v.49, n.1, p.12-14, 1965.

16. Macedo, R.L.G.; Venturin, N.; Pereira, A.V.; De Lima, P.O.; Araújo, C.; Do Vale, R.S. Estabelecimento e Crescimento Inicial de Clones de Hevea sp. na Região de Paracatu-MG. Cerne, Lavras, MG, v.15, n.1, p.84-91, 2009.

17. Mattos, C.R.R.; Garcia, D.; Pinard, F.; Le Guen, V. Variabilidade de isolados de Microcyclus ulei no Sudeste da Bahia. Fitopatologia Brasileira, Brasília, DF, v.28, p.502-507, 2003.

18. Miller, J.W. Differential clones of Hevea for identifying species of Dothidella ulei. Plant Disease Reporter, Beltsville, v.50, n.3, p.187-190, 1966.

19. Paiva, J.R.; Kalil Filho, A.N. Melhoramento genético de seringueira. 
Informe Agropecuário, Belo Horizonte, v.11, n.121, p.52-58, 1985.

20. Peralta, A.M.; Furtado, E.L.; Amorim, L.; Menten, J.O.M.; Bergamin Filho, A. Melhoramento para resistência ao mal das folhas da seringueira: revisão. Summa Phytopathologica, Botucatu, SP, v.16, p.214-224, 1990.

21. Parleviliet, J.E. Plant pathosystems: an attempt to elucidate horizontal resistance. Euphytica, Wageningen, Netherlands, v.26, p.553-556, 1977.
22. Sambugaro, R.; Furtado, E.L.; Rodella, R.A.; Mattos, C.R.R. Anatomia foliar de seringueira (Hevea spp.) e desenvolvimento da infecção por Microcyclus ulei. Summa Phytopathologica, Botucatu, SP, v.30, n.1, p.51-56, 2004.

23. Vanderplank, J.E. Plant diseases: epidemics and control. New York: Academic Press, 1963. 